\title{
Letter to the Editor: "Circulating Cell-Free DNA and Circulating Tumor Cells as Prognostic and Predictive Biomarkers in Advanced Non-Small Cell Lung Cancer Patients Treated with First-Line Chemotherapy"
}

\author{
Chiara Nicolazzo, Cristina Raimondi, Flavia Loreni, Paola Gazzaniga and Angela Gradilone * \\ Circulating Tumor Cells Unit, Department of Molecular Medicine, Sapienza University of Rome, Viale Regina \\ Elena, 324, 00161 Rome, Italy; chiara.nicolazzo@uniroma1.it (C.N.); cristina.raimondi@libero.it (C.R.); \\ flavialoreni91@gmail.com (F.L.); paola.gazzaniga@uniroma1.it (P.G.) \\ * Correspondence: angela.gradilone@uniroma1.it; Tel.: +39-06-445-1286
}

Academic Editors: William Chi-shing Cho and Stephen A. Bustin

Received: 5 June 2017; Accepted: 16 June 2017; Published: 19 June 2017

\section{To the Editor,}

We read with great interest the article "Circulating Cell-Free DNA and Circulating Tumor Cells as Prognostic and Predictive Biomarkers in Advanced Non-Small Cell Lung Cancer Patients Treated with First-Line Chemotherapy" published by Coco, S. et al. in International Journal of Molecular Sciences on 11 May 2017 [1]. The aim of the authors was to evaluate the prognostic role of cell-free tumor DNA (cfDNA) quantification and circulating tumor cells (CTCs) enumeration, separately or conjunctionally, in non-small cell lung cancer (NSCLC) patients receiving first line chemotherapy. Based on their data, the authors concluded that cfDNA demonstrated a more reliable biomarker than CTCs in the overall population. However, the CTC analysis was performed based on morphological characteristics, such as nuclear size, nuclear/cytoplasmic ratio, hyperchromatic nucleus and nuclear membrane irregularities. In this regard, we would like to make a few comments, which are mainly technical in nature.

The authors chose a device (ScreenCell Cyto, ScreenCell, Sarcelles, France) which is simple, inexpensive and allows to study the biological characteristics of CTCs isolated from $3 \mathrm{~mL}$ of blood. Nevertheless, Haematoxylin-Eosin (H\&E) staining alone does not allow a correct enumeration of CTCs, which would necessitate further molecular characterization for cancer-specific biomarkers, such as, in this case, thyroid transcription factor 1 (TTF-1) for adenocarcinomas and high-molecular weight (HMW) keratins (CK5/6) for squamous-cell carcinomas [2].

Indeed, as early as 2013, El-Heliebi et al. reported that reliable detection of CTCs should be confirmed by immunocytochemical and/or molecular biological methods [3]. Thus, beyond the tumor cells' heterogeneity, it is conceivable that a leukocyte subpopulation is present among the cells isolated on the filter and could lead to a CTC number overestimation in the present work.

Furthermore, the association between a higher number of CTCs and better prognosis is definitely uncommon and would deserve further discussion. Our feeling is that, similarly to what is reported by Juan et al. [4], the authors should re-consider that the use of H\&E staining alone, as the only criterion for CTCs identification, may lead to an overestimation of CTC number in their clinical records.

As a suggestion, the authors could perform a leukocytes depletion before detecting CTCs by using a ScreenCell Cyto kit [5] and subsequently characterize such cells through a multiplex immunofluorescence for 4',6-diamidino-2-phenylindole (DAPI), TTF-1 and HMW keratins, to discriminate the real CTCs from other cells, followed by H\&E staining. This is the only way to confirm the specificity and the sensibility of the morphological examination after H\&E assay.

We hope that our observation and advice will be accepted as a productive analysis. 
Conflicts of Interest: The authors declare no conflict of interest.

\section{References}

1. Coco, S.; Alama, A.; Vanni, I.; Fontana, V.; Genova, C.; Dal Bello, M.G.; Truini, A.; Rijavec, E.; Biello, F.; Sini, C.; et al. Circulating Cell-Free DNA and Circulating Tumor Cells as Prognostic and Predictive Biomarkers in Advanced Non-Small Cell Lung Cancer Patients Treated with First-Line Chemotherapy. Int. J. Mol. Sci. 2017, 18, 1035. [CrossRef] [PubMed]

2. Raimondi, C.; Carpino, G.; Nicolazzo, C.; Gradilone, A.; Gianni, W.; Gelibter, A.; Gaudio, E.; Cortesi, E.; Gazzaniga, P. PD-L1 and epithelial-mesenchymal transition in circulating tumor cells from non-small-cell lung cancer patients: A molecular shield to evade immune system? OncoImmunology 2017. [CrossRef]

3. El-Heliebi, A.; Kroneis, T.; Zöhrer, E.; Haybaeck, J.; Fischereder, K.; Kampel-Kettner, K.; Zigeuner, R.; Pock, H.; Riedl, R.; Stauber, R.; et al. Are morphological criteria sufficient for the identification of circulating tumor cells in renal cancer? J. Transl. Med. 2013, 11, 1-17. [CrossRef] [PubMed]

4. Juan, O.; Vidal, J.; Gisbert, R.; Muñoz, J.; Maciá, S.; Gómez-Codina, J. Prognostic significance of circulating tumor cells in advanced non-small cell lung cancer patients treated with docetaxel and gemcitabine. Clin. Transl. Oncol. 2014, 16, 637-643. [CrossRef] [PubMed]

5. Nicolazzo, C.; Raimondi, C.; Francescangeli, F.; Ceccarelli, S.; Trenta, P.; Magri, V.; Marchese, C.; Zeuner, A.; Gradilone, A.; Gazzaniga, P. EpCAM-expressing circulating tumor cells in colorectal cancer. Int. J. Biol. Markers 2017. [CrossRef] [PubMed]

(C) 2017 by the authors. Licensee MDPI, Basel, Switzerland. This article is an open access article distributed under the terms and conditions of the Creative Commons Attribution (CC BY) license (http://creativecommons.org/licenses/by/4.0/). 